Dinamika Sosial Budaya, Vol 19, No. 2, Desember 2017, pp 318-328

p-ISSN: 1410-9859\& e-ISSN: 2580-8524

http://journals.usm.ac.id/index.php/jdsb

\title{
OPTIMALISASI PEMBIAYAAN MURABAHAH BERPRINSIP BAGI HASIL PADA BANK SYARIAH DI INDONESIA 2010 - 2015
}

\author{
Windasari Rachmawati \\ Program Studi Akuntansi, Fakultas Ekonomi, Universitas Semarang, \\ windasarirachmawati@yahoo.com \\ Abdul Karim \\ Program Studi Akuntansi, Fakultas Ekonomi, Universitas Semarang \\ abdulkarim.akt@gmail.com \\ Abdul Manan \\ Program Studi Akuntansi, Fakultas Ekonomi, Universitas Semarang \\ ham11smg@gmail.com
}

\begin{abstract}
ABSTRAK
Penelitian ini ingin mengidentifikasi apakah faktor faktor DPK,NPF, Inflasi dan CAR berpengaruh terhadap pembiayaan murabahah. Metode penelitian dengan menggunakan alat uji statistic regresi berganda.Salah satu produk dari bank syariah yang sedang booming saat ini adalah pembiayaan Murabahah.Pembiayaan murabahah merupakan jual beli barang pada harga asal dengan tambahan keuntungan yanng disepakati.Istilah teknis perbankan syari'ah murabahah ini diartikan sebagai suatu perjanjian yang disepakati antara Bank Syariah dengan nasabah, dimana Bank memberikan pembiayaan untuk pembelian bahan baku atau modal kerja lainnya yang dibutuhkan nasabah, yang akan dibayar kembali oleh nasabah sebesar harga jual bank (harga beli bank + margin keuntungan) pada waktu yang ditetapkan. Penelitian ini dilakukan untuk menguji pengaruh variabel DPK, NPF, INFLASI dan CAR terhadap pembiayaan murabahah pada perbankan syariah yang terdaftar di bank Indonesia selama periode 2010-2015.Kriteria pemilihan sampel menggunakan purposive sampling.Sampel penelitian sebanyak 12 perusahaan perbankan syariah.Berdasarkan hasil analisis dan pembahasan yang dilakukan maka dapat ditarik kesimpulan bahwa variabel independen dalam penelitian ini yang diukur menggunakan komite DPK, Inflasi, NPF tidak berpengaruh terhadap pembiayaan murabahah, hal ini dikarenakan penerapan pembiayaan murabahah belum dikenal masyarakat luas, jika dibandingkan pembiayaan mudharabah dan pembiayaan mutlaqah. Hal ini dapat dilihat rata - rata selama tahun 2010 - 2015 . DPK dengan tingkat signifikansi 0,522>0.005, inflasi 0,415>0,005, dan NPF 0,512>0.005.Sedangkan capital asset ratio berpengaruh terhadap pembiayaan murabahah dengan nilai signifikansi $0,001<0,005$.
\end{abstract}

Kata Kunci: DPK, NPF, Inflasi, CAR, pembiayaan murabahah

\begin{abstract}
This study research aim to identify whether the factors of DPK, NPF, Inflation and CAR have an effect on murabaha financing. The research method using multiple regression statistic test. One of the products of Islamic banks that are currently booming is Murabahah financing. Murabahah financing is the sale and purchase of goods at the price of origin with additional profits yanng agreed. The technical term of syari'ah murabahah banking is defined as an agreement agreed between Bank Syariah with customers, where the Bank provides financing for the purchase of raw materials or other working capital required by the customer, which will be repaid by the customer at the selling price of the bank (the purchase price of the profit margin bank) at the stipulated time. This study was conducted to examine the effect of DPK, NPF, INFLATION and CAR variables on murabahah financing in sharia banks registered in Indonesian banks during the period 2010-2015. The criteria for selecting samples using purposive sampling. The sample of research is 12 sharia banking companies.Based on the results of the analysis and discussion conducted it can be concluded that the independent variables in this study measured using the committee $D P K$, Inflation, NPF does not affect murabahah financing, this is because the murabahah financing is not well known public, when compared to mudharabah financing and mutlaqah financing. This can be seen on average during the years 2010 - 2015. DPK with a significance level of 0.522>0.005, inflation 0.415>0.005, and NPF $0.512>0.005$. Capital asset ratio affects murabahah financing with a value of $0.001<0.005$.
\end{abstract}

Keywords: DPK, NPF, Inflation, CAR, Murabahah financing 
Dinamika Sosial Budaya, Vol 19, No. 2, Desember 2017, pp 318-328

p-ISSN: $1410-9859 \&$ e-ISSN: $2580-8524$

http://journals.usm.ac.id/index.php/jdsb

\section{PENDAHULUAN}

Kinerja perbankan syariah Indonesia pada tahun 2015 yang menggembirakan berdampak positif terhadap perkembangan perbankan di Indonesia, terutama perbankan syariah. Menurut statistik perbankan syariah tahun 2015 yang diterbitkan oleh bank Indonesia menyatakan secara nasional volume usaha perbankan syariah yang terdiri atas total aset, total dana pihak ketiga dan total pembiayaan yang disalurkan bank syariah meningkat. Total aset pada tahun 2014 yang hanya Rp 204Miliyar meningkat menjadi Rp 213 Miliyar, total dana pihak ketiga pada tahun 2014 sebesar Rp 159 Miliyar menjadi Rp 164 Miliyar, sedangkan total pembiayaan yang disalurkan pada tahun 2014 sebesar Rp 187 Miliyar menjadi Rp 199 Miliyar pada tahun 2015.Pemerintah dalam hal ini sudah mengatur di dalam undang - undang no. 21 tahun 2008 tentang perbankan syariah yang menyatakan bahwa perbankan syariah adalah segala sesuatu yang menyangkut tentang bank syariah dan unit usaha syariah mencakup kelembagaan, kegiatan usaha, serta cara dan proses dalam melaksanakan kegiatan usahanya. Bank adalah badan usaha yang menghimpun dana dari masyarakat yaitu simpanan masyarakat dalam bentuk kredit dan atau bentuk lainnya dalam rangka meningkatkan taraf hidup masyarakat.Sektor perbankan sebagai lembaga intermediasi antara pihak - pihak yang memiliki kelebihan dana dengan pihak - pihak yang memerlukan dana, diperlukan bank dengan kinerja keuangan yang sehat, sehingga fungsi intermediasi dapat berjalan lancar.Berdasarkan uraian di atas, perumusan dalam penelitian ini adalah bank syariah memiliki resiko pembiayaan murabahah, oleh karena itu peneliti ingin mengetahui DPK, NPF, inflasi dan CAR yang sangat fluktuasi mempengaruhi optimalisasi pembiayaan murabahah berprinsip bagi hasil pada perbankan syariah selama tahun $2010-2015$.

\section{DPK(Dana Pihak Ketiga)}

Simpanan (Dana Pihak Ketiga)Menurut Undang-Undang Nomor 10 Tahun 1998 tentang Perbankan(Pasal 1) disebutkan bahwa, "Simpanan adalah dana yang dipercayakan olehmasyarakat kepada bank berdasarkan perjanjian penyimpanan dana dalambentuk giro, deposito, tabungan dan atau bentuk lainnya yang dipersamakanitu".Dana pihak ketiga (DPK) merupakan dana yang dipercayakan masyarakat (di luar bank) kepada bank berdasarkan perjanjian penyimpanan dana (Rinaldy,2008). Produk penghimpunan dana di bank syariah seperti giro wadiah, tabungan wadiah, tabungan dan deposito mudharabah.Pada penelitian Khodijah Hadiyyatul Maula (2009) menunjukkan bahwa variabel simpanan (dana pihak ketiga) menunjukkan bahwa variabel simpanan(dana pihak ketiga) berpengaruh negatif terhadap pembiayaan murabahah. Sedangkan penelitian Nurhayati Siregar (2012), DPK berpengaruh positif terhadap penyaluran dana. H1: Dana pihak ketiga berpengaruh terhadap pembiayaan murabahah.

\section{Non Performing Finance (NPF)}

Menururt Djoko Renadi (2006), batasan maksimal NPF bagi perbankan nasional pada saat ini sudah mendesak untuk dijadikan ukuran yang penting dikaitkan dengan keberhasilan kinerja keuangan sebuah bank. Angka NPF merupakan salah satu indikator penting dalam pengukuran tingkat tingkat kesehatan bank, maka seluruh bank akan tetap berusaha menekan angka NPF ini, jika perlu bank tersebut tidak melakukan ekspansi kredit 
Dinamika Sosial Budaya, Vol 19, No. 2, Desember 2017, pp 318-328

p-ISSN: 1410-9859\& e-ISSN: 2580-8524

http://journals.usm.ac.id/index.php/jdsb

jika mereka tidak yakin terhadap prospek debitur yang dibiayai. Angka NPF dan CAR merupakan dua indikator prinsip kehati-hatian bank yang harus dijaga di dalam setiap melakukan ekspansi kredit. Bank Indonesia selaku Bank sentral dan pengawas perbankan di Indonesia memberikan ketentuan ukuran penilaian tingkat kesehatan Bank.Salah satu ketentuan BI mengenai NPF adalah Bank-Bank harus memiliki NPF kurang dari 5\%.

Hendarwati (2005) meneliti tentang Pengaruh Simpanan, Nisbah Bagi Hasil dan NPF Terhadap Pembiayaan menyimpulkan bahwa secara keseluruhan variabel independen yang terdiri dari simpanan, nisbah bagi hasil, NPF (Non Performing Financing) mempengaruhi variabel dependen (jumlah pembiayaan). Berbeda dengan hasil penelitian Fuadah (2002) mengungkapkan bahwa simpanan dan modal sendiri sebagai variabel independen berpengaruh terhadap besarnya pembiayaan investasi yang diberikan oleh bank syariah mandiri tetapi Non Performing Financing (NPF) tidak berpengaruh terhadap besarnya pembiayaan investasi yang diberikan oleh bank syariah mandiri.

H2; NPF berpengaruh terhadap pembiayaan murabahah

\section{Inflasi}

Inflasi adalah naiknya harga - harga komoditi secara umum yang secara nyata adanya tida singkronnya program pengadaan komoditi (produksi, penentuan harga, percetakan uang dan sebagainya) atau dengan kata lain adanya penurunan dari nilai mata uang yang berlaku. Inflasi merupakan suatu kejadian yang menggambarkan situasi dan kondisi dimana harga barang mengalami kenaikan dan nilai mata uang mengalamipelemahan, dan jika ini terjadi secara terus menerus maka akan mengakibatkanpada memburuknya kondisi ekonomi secara menyeluruh termasuk kondisiperbankan (Irham Fahmi, 2011). Menurut Rachmat dan Maya (2011), inflasimerupakan kecenderungan meningkatnya harga barang-barang pada umumnyasecara terusmenerus yang disebabkan oleh karena jumlah uang yang beredarterlalu banyak dibandingkan dengan barang-barang dan jasa yang tersedia.Sukirno(1998) ada 3 akibat penting inflasi paada investasi:

1. inflasi menimbulkan penanaman modal secara spekulatif

2. tingkat bunga meningkat sehingga mengurangi investasi

3. menimbulkan ketidakpastian investasi di masa mendatang

Secara teoritis inflasi sangat berpengaruh terhadap industri perbankan, tak terkecuali perbankan syariah.Putri ( dalam hidayati,2007) menemukan bahwa kenaikan inflasi mengakibatkan penurunan DPK perbankan syariah. Karena pangsa pasar konsumen dari perbankan syariah dalam kategori pasar mengambang (floating market), yang lebih bersifat returned oriented. Penurunan DPK akan mengurangi kemampuan bank syariah dalam mengelola likuiditasnya dan menurunkan jumlah pembiayaan yang disalurkan. Jihad dan honsen (2009) menemukan bahwa inflasi akan mempengaruhi pembiayaan murabahah secara negatif

$\mathrm{H} 3$; inflasi berpengaruh secara negatif terhadap pembiayaan murabahah

\section{Capital Adequency Ratio (CAR)}

CAR (Capital Adequacy Ratio)memproxykan penilaian terhadap aspek permodalan bank. Rasio CAR adalah kecukupan modal yang 
Dinamika Sosial Budaya, Vol 19, No. 2, Desember 2017, pp 318-328

p-ISSN: 1410-9859\& e-ISSN: 2580-8524

http://journals.usm.ac.id/index.php/jdsb

menunjukkan kemampuan bank dalam

mempertahankan modal yang mencukupi dan

kemampuan manajemen bank dalam

mengidentifikasi, mengukur, mengawasi, dan

mengontrol risiko-risiko yang dapat berpengaruh terhadap besarnya moda bank. (Wibowo: 2007).Muhammad Ghafur (2007) menyebutkan bahwa variabel CAR (permodalan) pada $t$ berpengaruh negatif terhadap pembiayaan, sedangkan pada t-1 pengaruhnya adalah positif dan signifikan.Sedangkan penelitian yang dilakukan oleh Meydianawati (2007), hasil analisis menunjukkan bahwa variabel CAR berpengaruh positif dan signifikan terhadap penawaran kredit investasi dan kredit modal kerja bank umum kepada sektor UMKM.

H4; CAR berpengaruh terhadap pembiayaan murabahah

\section{METODE}

Dalam melaksanakan penelitian ini, data yang dipergunakan adalah data sekunder yang berupa laporan historis rasio-rasio keuangan masing-masingperusahaan perbankan syariah yang dilaporkan ke otoritas jasa keuangan serta laporan keuangan yang berupa laporan keuangan tahunan (annual report) untuk periode 2010 - 2015. Data annual report diperoleh melalui website resmi bank umum syariah di Indonesia serta otoritas jasa keuangan (www.ojk.go.id).

Populasi penelitian adalah seluruh bank umum syariah yang ada di Indonesia yang berjumah sebanyak 12 bank dan semua dijadikan obyek penelitian atau metode sensus. Adapun bank umum syariah yang diteliti mempunyai data laporan tahunan lengkap yang dilaporkan ke OJK atau otoritas jasa keuangan secara terus menerus dari tahun 2010 sampai dengan 2015.

Sampel penelitian diambil secara purposive sampling, dimanasampel digunakan apabila memenuhi kriteria sebagai berikut:

a. Perusahaan perbankan syariah pada kurun waktu penelitian (periode 2010-2015).

b. Tersedia data laporan keuangan selama kurun waktu penelitian(periode 2010 2015).

c. Bank yang diteliti masih beroperasi pada periode waktu penelitian(periode 2010 2015).

Berdasarkan pada kriteria pengambilan sampel seperti yang telahdisebutkan di atas, maka jumlah sampel yang digunakan dalam penelitianini adalah 12 bank.

\section{Capital adequency ratio}

Rasio ini dapat dirumuskan sebagai berikut (SE BI No 6/73/INTERNDPNP tgl 24 Desember 2004): rasio ini dapat menjelaskan kecukupan modal bank dalam pemenuhan kewajiban penyediaan modal minimum (KPMM)terhadap ketentuan yang berlaku. Adapun rumus capital adequency ratio adalah:

$$
\mathrm{CAR}=\underline{\text { Modal sendiri }}
$$

$$
\text { ATMR } \quad x 100 \%
$$

\section{Inflasi}

Tingkat inflasi regional per bulan yang menjadi sebuah indikator untuk melihat tingkat perubahan dan di anggap terjadi jika proses kenaikan harga berlangsung secara terus menerus dan saling mempengaruhi.Inflasi dalam penelitian ini diperoleh dari data sekunder. Ukuran dari risiko yang sistematis disebut juga dengan koefisien beta ( $\beta$ )yaitu ukuran yang menunjukkan kepekaan 
Dinamika Sosial Budaya, Vol 19, No. 2, Desember 2017, pp 318-328

p-ISSN: 1410-9859\& e-ISSN: 2580-8524

http://journals.usm.ac.id/index.php/jdsb

tingkat keuntungan (return) terhadapperubahan keuntungan pasar (market return). Menurut Mumtaz (2012) adapun besaran sensitivitas inflasi(beta inflasi) dalam penelitian ini diambil dengan cara meregres data inflasiselama periode amatan dengan ROA bank dalam periode amatan yang sama.

$\mathrm{INF}=\alpha \mathrm{i}+\beta \mathrm{i} .(\mathrm{ROA})+\mathrm{e}$

Dimana :

INF $=$ tingkat inflasi

$\alpha \mathrm{i}=$ intersep dari regresi

ROA = Return on Asset masing-masing bank

$\beta \mathrm{i}=$ beta inflasi, merupakan koefisien yang mengukur perubahan INF,akibat dari perubahan ROA

$\mathrm{e} \quad=$ error term

\section{Non Performing Financing}

Non performing finance merupakan suatu rasio tingkat kredit bermasalah yang dihadapi oleh bank, adapun rumus NPF adalah:

$\mathrm{NPF}=$ pembiayaan tidak lancar

Total pembiayaan

Untuk mengetahui tingkat kesehatan non performing finance masing - masing bank syariah maka akan dikategorikan sebagai berikut:

\section{Dana Pihak Ketiga (DPK)}

Dana pihak ketiga (DPK) merupakan dana yang dipercayakan masyarakat (di luar bank) kepada bank berdasarkan perjanjian penyimpanan dana (Rinaldy, 2008).

Rumus perhitungan Dana Pihak Ketiga (DPK):

Dana Pihak Ketiga $=$ Giro + Deposito + Tabungan

\section{Variabel Dependen}

Variabel dependen dalam penelitian ini adalah Pembiayaan Murabahah.Murabahah adalah jual beli barang pada harga asal dengan harga keuntungan yang disepakati (Syafi'I Antonio:
2001). Ba'i al murabahah dapat dilihat dari total atau jumlah pembiayaan murabahah yang disalurkan.

\section{HASIL DAN PEMBAHASAN}

\section{UJI NORMALITAS DATA}

Uji normalitas bertujuan menguji apakah dalam model regresi, variabel dependen dan variabel independen keduanya mempunyai distribusi normal atau tidak.Model regresi yang baik adalah memiliki distribusi normal atau mendekati normal.Untuk mendeteksi normalitas dapat dilakukan dengan uji statistic. Tes statistic yang digunakan antara lain analisis grafik histogram, normal probability plots dan kolmogorov - smirnov test (Imam Ghozali, 2001).

\section{HASIL UJI NORMALITAS DATA}

One-Sample Kolmogorov-Smirnov Test

\begin{tabular}{|c|c|c|}
\hline & & $\begin{array}{l}\text { Unstandardiz } \\
\text { ed Residual }\end{array}$ \\
\hline \multicolumn{2}{|l|}{$\bar{N}$} & 66 \\
\hline \multirow[t]{2}{*}{ Normal Parameters ab. } & Mean & .0000000 \\
\hline & Std. Doviation & 50.87740217 \\
\hline \multirow{3}{*}{ Differences } & Absolite & .112 \\
\hline & Positive & .112 \\
\hline & Negative & -.059 \\
\hline Kolmogorov-Smimov Z & & 912 \\
\hline Asymp Sig (2-tailed) & & .376 \\
\hline
\end{tabular}

Sumber: data spss yang diolah 2017

Hasil sampel pada tabel 4.2.1 tersebut menunjukkan bahwa nilai kolmogrov - smirnov untuk:

1. Dana pihak ketiga sebesar $-0,217$ dan tingkat signifikan pada 0,522 (karena $\mathrm{p}=0,522>$ dari 0,05). Jadi tidak dapat menolak H0 yang mengatakan bahwa residual terdistribusi secara normal atau dengan kata lain residual berdistribusi normal. 
Dinamika Sosial Budaya, Vol 19, No. 2, Desember 2017, pp 318-328

p-ISSN: 1410-9859\& e-ISSN: 2580-8524

http://journals.usm.ac.id/index.php/jdsb

2. Inflasi sebesar 2,568 dan tingkat signifikan pada 0,415 (karena $\mathrm{p}=0,415>$ dari 0,05 ). Jadi tidak dapat menolak $\mathrm{HO}$ yang mengatakan bahwa residual terdistribusi secara normal atau dengan kata lain residual berdistribusi normal.

3. NPF sebesar 2,977dan tingkat signifikan pada 0,512 (karena $\mathrm{p}=0,512>$ dari 0,05). Jaditidak dapat menolak H0 yang mengatakan bahwa residual terdistribusi secara normal atau dengan kata lain residual berdistribusi normal.

4. CAR sebesar 1,428 dan tingkat signifikan pada 0,001 (karena $\mathrm{p}=0,001>$ dari 0,05 ). Jadi tidak dapat menolak H0 yang mengatakan bahwa residual terdistribusi secara normal atau dengan kata lain residual berdistribusi normal.

Pengujian normalitas data adalah pengujian tentang kenormalan distribusi data. Uji normalitas bertujuan menguji apakah dalam model regresi memiliki distribusi normal. Uji normalitas diuji dengan menggunakan uji Kolmogorov Smirnov dengan membuat hipotesis.

\section{UJI MULTIKOLONIERITAS}

Pengujian asumsi kedua adalah uji multikolonieritas (multicolonierity) antara variabel variabel independen yang masuk ke dalam model. Metode untuk mendiagnose adanya multikolonearity dilakukan dengan diduganya korelasi (r) diatas 0,70 (singgih santoso, 1999: 262); dan ketika korelasi derajat nol juga tinggi, tetapi tak satupun atau sangat sedikit koefisien regresi parsial yang secara individu signifikan secara statistic atas dasar pengujian $t$ yang konvensional (Gujarati, 1995: 166). Disamping itu juga dapat digunakan uji variance inflation factor (VIF) yang dihitung dengan rumus sebagai berikut: $\mathrm{VIF}=1 /$ Tolerence
Jika VIF lebih besar dari 10, maka antara variabel bebas terjadi persoalan multikolinearitas

Hasil Uji Multikolinieritas

Uji Heteroskedasitas dan Autokorelasi

Uji heteroskedastisitas dalam penelitian ini menggunakan uji Glejser. Uji ini dilakukan dengan meregres nilai absolute residual terhadap variabel independen. Jika variabel independen signifikan secara stastistik mempengaruhi variabel dependen (absolute residual), maka ada indikasi terjadi Heteroskedastisitas.

Model regresi yang baik adalah yang homoskedastisitas atau tidak terjadi heteroskedasitas. Deteksi ada tidaknya problem heteroskedasitas adalah dengan media scatterpolt, apabila grafik membentuk pola khusus maka model terjadi heteroskedasitas. Tetapi jika ada pola yang jelas, serta titik - titik menyebar si atas dan di bawah angka 0 pada sumbu $\mathrm{Y}$, maka tidak terjadi heteroskedasitas.

Hasil uji heteroskedastisitas sebagai berikut :

Scatterplot

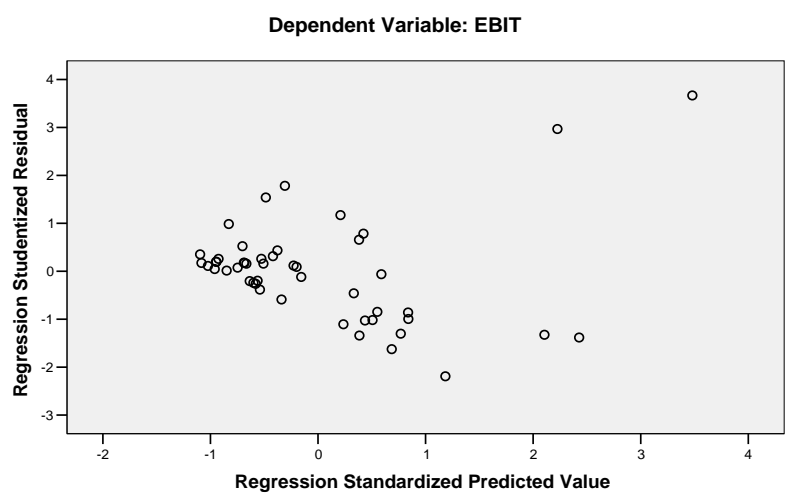

membentuk bisa membentuk pola tertentu yang jelas, dimana titik - titik menyebar di atas dan di bawah angka 0 pada sumbu $Y$, sehingga grafik tersebut tidak bias dibaca dengan jelas. Hasil ini memperlihatkan bahwa tidak terjadi heteroskedasitas.

Autokorelasi sering dikenal dengan nama korelasi serial dan sering ditemukan pada data serial 
Dinamika Sosial Budaya, Vol 19, No. 2, Desember 2017, pp 318-328

p-ISSN: 1410-9859\& e-ISSN: 2580-8524

http://journals.usm.ac.id/index.php/jdsb

waktu (time series). Uji autokorelasi bertujuan menguji apakah dalam model regresi ada korelasi antara kesalahan penggunaan pada periode $\mathrm{t}$ dengan kesalahan penggunaan pada periode t-1(sebelumnya). Model regresi yang baik adalah regresi yang bebas dari autokorelasi. Alat ukur yang digunakan untuk mendeteksi adanya autokorelasi dalam penelitian ini menggunakan Tes Durbin Watson (D-W). Uji Durbin Waston hanya digunakan untuk autokorelasi tingkat satu (first order autocorrelation) dan mensyaratkan adanya intercept (konstanta) dalam model regresi dan tidak ada variabel lag di antara variabel independen. Hasil uji autokorelasi ini dapat dilihat pada tabel 5.4 berikut ini:

\section{Model Summary}

\begin{tabular}{l|r|r|r|r|}
\hline Model & $\mathrm{R}$ & R Square & $\begin{array}{r}\text { Adjusted } \\
\text { R Square }\end{array}$ & $\begin{array}{r}\text { Std. Error } \\
\text { the Estimat }\end{array}$ \\
\hline 1 & $.45 \mathrm{P}$ & .203 & .151 & 52.5190 \\
\hline
\end{tabular}
a.Predictors: (Constant), CAR (X4), NPF NET (X
(X2), DPK (X1)
b. Dependent Variable: Pembiayaan Murabahah

Hasil uji menggunakan Durbin-Watson pada model regresi menunjukkan besarnya nilai Durbin-Watson adalah 1,764. Untuk menentukan ada atau tidaknya autokorelasi positif atau negatif pada model digunakan rumus sebagai berikut : du : Batas atas dari Tabel Durbin-Watson pada $\mathrm{N}=48$ dan $\mathrm{K}=3 \mathrm{~d}$ : Besarnya Nilai Durbin-Watson

maka dapat dihitung sebagai berikut : $d u<d<3-d u$
$1,116<1,764<3-1,116$
$1,116<1,764<$

1,879

Berdasarkan perhitungan tersebut dapat disimpulkan bahwa tidak ada autokorelasi positif dan negatif pada model regresi.

Analisis Regresi Linier Berganda

Uji Signifikansi Parameter Individual (Uji statistik t)

Regresi linier berganda ingin menguji pengaruh dua atau lebih variabel independen terhadap satu variabel dependen (Ghozali, 2009) yang dinyatakan sebagai berikut:

$\mathrm{Y}=\alpha+(\beta 1 \mathrm{DPK})+(\beta 2 \mathrm{INFLASI})+(\beta 3 \mathrm{NPF})$ $+(\beta 4 \mathrm{CAR})+\mathrm{e}$

$\mathrm{Y}=236.313+-0,217 \mathrm{DPK}+2,568$ INFLASI+ 2.977 $\mathrm{NPF}+1.428 \mathrm{CAR}+\mathrm{e}$

Untuk mengetahui pengaruh variabel dependen yaitulaba terhadap variabel independen yaitu komite audit, proporsi dewan komisaris, kepemilikan instritusional, kepemilikan manajerial pengolahan data dilakukan dengan menggunakan bantuan Software SPSS 17. Hasil yang diperoleh selanjutnya akan diuji kemaknaan model tersebut secara simultan dan secara parsial. Berdasarkan data diperoleh hasil regresi linier berganda sebagai berikut:

Koefisien-koefisien persamaan regresi linier berganda pada tabel 4.3.1. dapat diartikan sebagai berikut:

1. Konstanta $(\alpha)$ sebesar 236.313 mempunyai arti apabila semua variabel independen sama dengan nol maka pembiyaan murabahah bank syariah bernilai sebesar 236.313 .

2. Koefisien regresi DPK sebesar -0,217 artinya setiap DPK sebesar 1 satuan menaikkan pembiyaan murabahah bank syariah sebesar 0,217 dengan asumsi faktor - faktor yang lain tetap atau ceteris paribus.

3. Koefisien regresiInflasi2,568 mempunyai arti setiap kenaikan inflasi sebesar 1 satuan akan menurunkan pembiayaan murabahahsebesar 2,568 satuan dengan asumsi faktor - faktor yang lain tetap atau ceteris paribus.

4. Koefisien regresi CAR sebesar 1,428 artinya setiap kenaikan rasio kepemilikan institusional sebesar 1 satuan menurunkan laba saham sebesar 1,428 satuan dengan asumsi faktor - faktor yang lain tetap atau ceteris paribus. 
Dinamika Sosial Budaya, Vol 19, No. 2, Desember 2017, pp 318-328

p-ISSN: 1410-9859\& e-ISSN: 2580-8524

http://journals.usm.ac.id/index.php/jdsb

Uji Parsial (Uji-t)

Uji statistik $t$ pada dasarnya menunjukkan seberapa jauh pengaruh satu variabel penjelas/independen secara individual dalam menerangkan variasi variabel dependen (Ghozali, 2011).

Koefisien regresi digunakan untuk mengetahui pengaruh variabel komite audit, proporsi dewan komisaris, kepemilikan institusinal dan kepemilikan manajerial secara parsial terhadap laba. Kriteria pengujian adalah:

1. Jika tingkat signifikansi lebih dari 5\% maka dapat disimpulkan bahwa Ho diterima, sebaliknya Ha ditolak.

2. Jika tingkat signifikansi lebih kecil dari 5\%, maka dapat disimpulkan bahwa Ho ditolak, sebaliknya Ha diterima

Variabel dana pihak ketiga,inflasi, npf, dan car. Hasil pengujian pengaruh variabel independen terhadap variabel dependennya sebagai berikut:

\section{Pengujian hipotesis pertama}

Ha1 : dana pihak ketiga berpengaruh negatif terhadap pembiayaan murabahah

Berdasarkan pada tabel 4.3.2 hasil uji regresi linier berganda diperoleh nilai koefisien regresi untuk sebesar -0,217. Hal ini menunjukkan bahwa hubungan antara dana pihak ketiga terhadap pembiayaan murabahah adalah tidak searah. Variabel DPK (X1) mempunyai t hitung sebesar -0,644 dengan signifikansi sebesar 0,522. Nilai signifikansi $t \quad D P K>0,05$ maka dapat disimpulkan DPKtidak berpengaruh terhadap pembiayaan murabahah sehingga hipotesis pertama ditolak.Ini bertentangan dengan penelitian yang dilakukan oleh Luh Gedhe Meydianawati (2007) dengan menggunakan variabel DPK, Capital Adequacy Ratio(CAR),
Non PerformingLoan (NPL), dan Return on Assets (ROA).Hasil analisis menunjukkan bahwavariabel-variabel Dana Pihak Ketiga (DPK), CAR, ROA berpengaruh positif dan signifikan terhadap penawaran kredit investasi dan kredit modal kerja bank umumkepada sektor UMKM. Sebaliknya mendukung penelitian Khodijah Hadiyyatul Maula (2009) dalam penelitiannya yang berjudul "Pengaruh Simpanan (Dana Pihak Ketiga), Modal Sendiri, Marjin Keuntungan danNPF (Non Performing Financing) terhadap Pembiayaan Murabahah pada BankSyariah Mandiri" menunjukkan bahwa variabel simpanan (dana pihak ketiga)berpengaruh negatif terhadap pembiayaan murabahah. Untuk variabel modalsendiri dan marjin keuntungan berpengaruh positif dan signifikan terhadappembiayaan murabahah.Dan NPF berpengaruh secara negatif dan signifikanterhadap pembiayaan murabahah.

\section{Pengujian Hipotesis Kedua}

Ha2 : inflasi berpengaruh negatif terhadap pembiayaan murabahah

Berdasarkan pada tabel 4.3.2 hasil uji regresi linier berganda diperoleh nilai koefisien regresi untuk inflasi sebesar 2,568. Hal ini menunjukkan bahwa hubungan antara inflasi terhadap pembiayaan murabahah adalah tidak searah. Variabel inflasi (X2) mempunyai t hitung sebesar 0,821 dengan signifikansi sebesar 0,415 . Nilai signifikansi t proporsi dewan komisaris> 0,05 maka dapat disimpulkan inflasi berpengaruh negatif dan signifikan terhadap pembiayaan murabahah sehingga hipotesis kedua ditolak. Hal ini mendukung dengan penelitian yang dilakukan oleh jihan dan hosen (2009), dengan hasil 
Dinamika Sosial Budaya, Vol 19, No. 2, Desember 2017, pp 318-328

p-ISSN: $1410-9859 \&$ e-ISSN: 2580-8524

http://journals.usm.ac.id/index.php/jdsb

penelitian inflasi tidak berpengaruh terhadap pembiayaan murabah.

\section{Pengujian Hipotesis Ketiga}

Ha3 : NPF berpengaruh negatif terhadap pembiayaan murabahah

Berdasarkan pada tabel 4.3.2 hasil uji regresi linier berganda diperoleh nilai koefisien regresi untuknon performing finance diperoleh nilai sebesar 2,977. Hal ini menunjukkan bahwa hubungan antara NPF terhadap pembiayaan murabahah tidak searah. Variabel non performing finance (X3) mempunyai $\mathrm{t}$ hitung sebesar 0,660dengan signifikansi sebesar 0,512. Nilai signifikansi $\mathrm{t}$ kepemiikan institusional $>0,05$ maka dapat disimpulkan NPF berpengaruh negatif terhadap pembiayaan murabahah sehingga hipotesis ketiga ditolak. Penelitian ini mendukung hasil penelitian Khodijah Hadiyyatul Maula (2009) dalam penelitiannya yang berjudul Pengaruh Simpanan (Dana Pihak Ketiga), Modal Sendiri, Marjin Keuntungan danNPF (Non Performing Financing) terhadap Pembiayaan Murabahah pada BankSyariah Mandiri menunjukkan bahwa variabel simpanan (dana pihak ketiga)berpengaruh negatif terhadap pembiayaan murabahah. Untuk variabel modalsendiri dan marjin keuntungan berpengaruh positif dan signifikan terhadap

pembiayaan murabahah. NPF berpengaruh secara negatif dan signifikanterhadap pembiayaan murabahah.

\section{Pengujian Hipotesis Keempat}

Ha4 : CAR berpengaruh positif terhadap pembiayaan murabahah

Berdasarkan pada tabel 4.3.2 hasil uji regresi linier berganda diperoleh nilai koefisien regresi untukCAR diperoleh nilai sebesar 1,428. Hal ini menunjukkan bahwa hubungan antara CAR terhadap pembiayaan murabahah searah. Variabel CAR (X4) mempunyai $t$ hitung sebesar 3,615dengan signifikansi sebesar 0,001. Nilai signifikansi t kepemiikan manajerial< 0,05 maka dapat disimpulkan CAR berpengaruh positif terhadap pembiayaan murabahah sehingga hipotesis keempat diterima. Sesuai dengan hasil penelitianLuh Gedhe Meydianawati (2007) dengan menggunakan variabel DPK, Capital Adequacy Ratio(CAR), Non PerformingLoan (NPL), dan Return on Assets (ROA).Hasil analisis menunjukkan bahwavariabel-variabel Dana Pihak Ketiga (DPK), CAR, ROA berpengaruh positif dansignifikan terhadap penawaran kredit investasi dan kredit modal kerja bank umumkepada sektor UMKM.Sedangkan variabel NPL berpengaruh negatif terhadappenawaran kredit investasi dan kredit modal kerja bank umum kepada sektor UMKM.

Uji Signifikansi Simultan (Uji F)

Uji F digunakan untuk menguji signifikansi model regresi. Tujuan dari uji $\mathrm{F}$ ini adalah untuk membuktikan secara statistik bahwa keseluruhan koefisien regresi yang digunakan dalam analisis ini signifikan. Apabila nilai signifikansi $\mathrm{F}$ lebih kecil dari 0,05 maka model regresi signifikan secara statistik.

Untuk menguji hipotesis ini digunakan statistik F dengan kriteria pengambilan keputusan sebagai berikut:

a) Bila nilai $\mathrm{F}$ lebih besar daripada 4 maka Ho dapat ditolak pada derajat kepercayaan 5\%, dengan kata lain menerima $\mathrm{Ha}$ yang menyatakan bahwa semua variabel independen secara simultan signifikan mempengaruhi variabel dependen. 
Dinamika Sosial Budaya, Vol 19, No. 2, Desember 2017, pp 318-328

p-ISSN: 1410-9859\& e-ISSN: 2580-8524

http://journals.usm.ac.id/index.php/jdsb

b) Membandingkan nilai $\mathrm{F}$ hasil perhitungan dengan nilai $\mathrm{F}$ menurut tabel. Bila nilai $\mathrm{F}$ hitung lebih besar daripada nilai $\mathrm{F}$ tabel, maka Ho ditolak dan menerima Ha. (Ghozali, 2011).

Pengujian signifikansi pengaruh variabel dana pihak ketiga, inflasi, non performing finance , dan capital asset ratioterhadap pembiayaan murabahah secara simultan dapat dilihat pada tabel 4.5 uji simultan, bahwa nilai $\mathrm{F}$ hitung sebesar 3,893dengan signifikansi sebesar 0,07. Nilai signifikansi $0,007>\quad 0,05$ menunjukkan bahwa variabel dana pihak ketiga,inflasi, non performing finance, dan CAR secara simultan tidak mempunyai pengaruh terhadap pembiayaan murabahah.

\section{Koefisien Determinasi (adjusted R square)}

Pada bagian ini dilakukan uji koefisien determinasi untuk menggambarkan seberapa besar perubahan atas variasi dari variable dependen yang dapat dijelaskan oleh perubahan atau variasi dari variabel independen. Koefisien determinasi atau adjusted $\mathrm{R}^{2}$ dapat dilihat pada tabel berikut:

Koefisien determinasi (Adjusted $\mathrm{R}^{2}$ )

Model summary

Model Summarb

\begin{tabular}{l|r|r|r|r|}
\hline Model & $\mathrm{R}$ & R Square & $\begin{array}{r}\text { Adjusted } \\
\text { R Square }\end{array}$ & $\begin{array}{r}\text { Std. Error of } \\
\text { the Estimate }\end{array}$ \\
\hline 1 & $.45 \mathrm{P}^{\mathrm{P}}$ & .203 & .151 & 52.51903 \\
\hline
\end{tabular}
a. Predictors: (Constant), CAR (X4), NPF NET (X3), Inflas
(X2), DPK (X1)
b. Dependent Variable: Pembiayaan Murabahah (Y)

Berdasarkan table 4.5 dapat dilihat angka koefisien determinasi ( Adjusted R square) sebesar 0,151 atau 10\%. Hal ini menunjukkan bahwa variabel independen berupa DPK,INFLASI, NPF dan CAR dapat menjelaskan variabel dependen (pembiayaan murabahah) sebesar 0,151 sisanya 90\% dijelaskan oleh variabel - variabel lain di luar penelitian ini.

\section{KESIMPULAN}

Berdasarkan hasil analisis dan pembahasan yang dilakukan maka dapat ditarik kesimpulan bahwa variabel independen dalam penelitian ini yang diukur menggunakan komite DPK, Inflasi, NPF tidak berpengaruh terhadap pembiayaan murabahah, hal ini dikarenakan penerapan pembiayaan murabahah belum dikenal masyarakat luas, jika dibandingkan pembiayaan mudharabah dan pembiayaan mutlaqah. Hal ini dapat dilihat rata - rata selama tahun 2010 2015. DPK dengan tingkat signifikansi 0,522>0.005, inflasi 0,415>0,005, dan NPF 0,512>0.005.Sedangkan capital asset ratio berpengaruh terhadap pembiayaan murabahah dengan nilai signifikansi $0,001<0,005$.

\section{Keterbatasan Penelitian}

Penelitian ini masih mempunyai beberapa keterbatasan diantaranya:

1. Keterbatasan dalam mengambil jenis bank umum yang digunakan sebagai sampel

2. Keterbatasan dalam menggunakan rasio keuangan perusahaan hanya diwakili oleh empat variabel, yaitu DPK, Inflasi, NPF dan CAR. Sebab terdapat kemungkinan variabel lain semisal ROA yang lebih signifikan pengaruhnya terhadap pembiayaan murabahah.

3. Subyektivitas peneliti dalam memahami laporan keuangan bisa mempengaruhi tingkat hasil penelitian.

\section{Saran}

Berdasarkan kesimpulan yang sudah diberikan, peneliti dapat memberikan saran sebagai berikut:

1. Adanya penambahan variabel pembiayaan murabahah. 
Dinamika Sosial Budaya, Vol 19, No. 2, Desember 2017, pp 318-328

p-ISSN: 1410-9859\& e-ISSN: 2580-8524

http://journals.usm.ac.id/index.php/jdsb

2. Bagi penelitian berikutnya diharapkan bisa melakukan uji beda antara variabel pembiayaan murabahah di bank umum syariah dengan Bank perkreditan rakyat syariah.

Agenda Penelitian Yang Akan Datang

Penelitian ini masih memungkinkan untuk dikembangkan lebih lanjut, oleh karena itu agenda penelitian mendatang diharapkan pada penelitian selanjutnya mungkin dapat menggunakan variable yang digunakan dalam penelitian ini dengan menambah variable lain atau bahkan melakukan perubahan variable yang menurut peneliti paling mempengaruhi manajemen laba di bursa efek Indonesia, dengan periode tahun yang lebih baru lagi

\section{Daftar Pustaka}

alma, iwan ( 2014), Analisis pengaruh dana pihak ketiga, sertifikat bank indonesia syariah, BI rate dan inflasi terhadap pembiayaan murabahah perbankan syariah di Indonesia periode 2006-2014,jurnal sains dan ekonomi perbankan syariah vol. 5. No. 1. Juli 2015
Bank Indonesia, (2007) Surat Edaran Bank Indonesia No. 9/24/DPbs tentang sistem penilaian tingkat kesehatan bank umum berdasarkan prinsip syariah

Bank Indonesia, (2014) Surat Edaran Bank Indonesia No. 9/24/DPbs tentang sistem penilaian tingkat kesehatan bank umum berdasarkan prinsip syariah

Mahliza, Netti (2011), Analisis faktor - faktor yang mempengaruhi realisasi pembiayaan murabahah untuk usaha mikro agribisnis sektor perdagangan (studi kasus: KBMT bil barkah, Bogor),jurnal fakultas ekonomi dan bisnis institut pertanian Bogor

Otoritas jasa keuangan (2015), statistik perbankan syariah 2015prastanto (2013), Analisis faktor - faktor yang mempengaruhi pembiayaan murabahah pada bank umum syariah Di Indonesia, jurnal unnes, vol.3 issn 2252-676

Sri wahyuni(2012) analisis pembiayaan murabahah pada bank mandiri syariah kota samarinda, Jurnal ekonomika bisnis Analisis, vol. 6 no. 1 hal. 47-54

Otoritas jasa keuangan (2015), statistik perbankan syariah 2015Subramanyam, K.R \& Wild, J.J. 2010. 